\title{
Not Asked
}

National Cancer Institute

\section{Source}

National Cancer Institute. Not Asked. NCI Thesaurus. Code C80217.

No inquiry was made to gather this information. 